\title{
Pengaruh Budaya Imperatif, Budaya Adiafora Dan Budaya Eksklusif Terhadap Keputusan Pembelian Produk Internasional Mcdonald's
}

\author{
Oleh: Alisia Melinda Purnama
}

\section{Pendahuluan}

Fast food merupakan makanan yang lebih mengutamakan cita rasa daripada kandungan gizi. Misalnya, keripik kentang yang mengandung garam. Beberapa junk food juga mengandung banyak gula misalnya, minuman bersoda, permen dan kue tar. Gula, tertutama gula buatan sangat tidak baik bagi kesehatan tubuh kita karena dapat menyebabkan penyakit diabetes, kerusakan pada gigi kita dan menyebabkan obesitas. Minuman bersoda mengandung paling banyak gula, sementara kebutuhan gula dalam tubuh tidak boleh lebih dari 4 gram atau satu sendok teh sehari (Griffindors (2013)).

Pada masa ini di Indonesia restoran fast food sudah sangat berkembang pesat. Seperti KFC (Kentucky Fried Chicken) yang pada saat ini sudah memiliki sekitar 540 gerai diseluruh Indonesia. Tahun 2016 diperkirakan ada tambahan 40 gerai lagi. KFC mudah disukai di Indonesia karena memajang menu ayam. Dikombinasikan dengan nasi, ini jelas bukan rasa yang asing di lidah warga Indonesia. Karena itu, tak perlu perkenalan atau adaptasi lidah terhadap menu-menu KFC. (tirto.id 2016)).

Selain KFC, Burger King juga salah satu restoran fast food yang cukup berkembang di Indonesia. Burger King mulai dioperasikan oleh Mitra Adiperkasa (yang juga mengoperasikan waralaba Starbucks), pada bulan April 2007, dengan outlet pertamanya di Senayan City, Jakarta. Saat ini, Burger King memiliki cabang-cabang di Jakarta, Bandung, Surabaya, Bali dan Lombok. (id.wikipedia.org). Restoran fast food yang berkembang pesat juga di Indonesia adalah McDonald's. Pada awalnya, McDonald's hanya menyajikan makanan yang berupa hamburger, ice cream, kentang goreng dan minuman bersoda. Setelah McDonald's memasuki pasar di Indonesia, harus menyesuaikan dengan lidah masyarakat Indonesia yang menjadikan nasi sebagai makanan pokoknya. Pada saat ini, McDonald's memiliki 168 gerai di Indonesia. Masih kalah saing dengan KFC yang memiliki 540 gerai di Indonesia. Negara Amerikat sendiri restoran fast food menguasai pangsa pasar yang relative besar. McDonald's 29\%, Subway 10\%,Burger King 8\%, Wendy's 8\%, Starbucks 7\%, Taco Bell 6\%, Pizza Hut 5\%,KFC 4\%, Sonic 3\%, Chickfil-A 3\%, Domino's Pizza 3\%, Panera Bread 3\%, Arby's 3\% dan lain-lain 3\%. (Source: QSR Magazine Presentase Penjualan Fast Food Restaurants di Amerika Serikat 2010).

Tabel 1.1.1

Daftar Top 11 Perusahaan Restoran Fast food di Indonesia Tahun 2016

\begin{tabular}{lllc}
\hline No & \multicolumn{1}{c}{ Nama Restoran } & \multicolumn{1}{c}{ Nama Perusahaan } & Gerai \\
\hline 1 & Kentucky Fried Chicken & Grup Gelael/PT Fast food Indonesia Tbk & 540 \\
\hline 2 & Pizza Hut & PT Sriboga Ratujaya & 200 \\
\hline 3 & A\&W & Yum! Brands Inc. & 200 \\
\hline 4 & California Fried Chicken & PT Pionerindo Gourmet Internasional Tbk & 183 \\
\hline 5 & Hoka-hoka Bento & Paulus Arifin/PT Eka Boganiti & 134 \\
\hline 6 & Texas Chicken & PT Cipta Selera Murni & 133 \\
\hline 7 & McDonald's & PT Rekso Nasional Food & 168
\end{tabular}




\begin{tabular}{lllc}
\hline 8 & Papa Ron's Pizza & PT Setiamandiri Mitratama Tbk & 34 \\
\hline 9 & Burger King & PT Sari Burger Indonesia & 18 \\
\hline 10 & Izzi Pizza & PT Sri Agung Cahaya Sakti & 6 \\
\hline 11 & Avenue Pizza & Jhon Lutsi/ PT Soho Musik & 3
\end{tabular}

Sumber: Majalah SWA Edisi: XXVII| 8-12 September 2016

Dari tabel di atas dapat kita lihat bahwa banyak sekali perusahaan yang berupa bisnis restoran berkembang pesat di negara Indonesia dan pada tahun 2009, usaha tersebut mulai meningkat. Memasuki daerah Jawa Barat dan kota-kota besar yang ada di dalamnya. Restoran fast food juga berkembang begitu pesat didaerah Jawa Barat dan kota-kota yang ada didalamnya seperti McDonald's, KFC, Burger King. Contoh kota di daerah Jawa Barat adalah Kota Bogor.

Kecenderungan penduduk di kota Bogor, bahwa makanan di restoran fast food masih dinilai memiliki nilai sosial atau gengsi tersendiri, yang mampu mengangkat kesan akan status dirinya. Di kota Bogor restoran fast food tidak hanya dijadikan sebagai tempat makan saja tetapi, untuk tempat perayaan acara-acara ulang tahun, syukuran, sambil rekreasi dan sebagainya. Bogor memiliki jumlah penduduk yang relative banyak yaitu sekitar 1.047.922 jiwa dan produktif. KFC, McDonald's, Burger King dan restoran fast food lainnya juga sudah berkembang cukup pesat di kawasan kota Bogor ini. Seperti McDonald's yang berkembang cukup pesat di Bogor.

Tabel 1.1.2

Daftar nama restoran McDonald's se-kota Bogor

\begin{tabular}{clc}
\hline No & \multicolumn{1}{c}{ Cabang Restoran } & Lokasi \\
\hline 1 & McDonald's Lodaya & Jl.Raya Padjajaran No.21 \\
\hline 2 & McDonald's Plaza Indah & Jl.KH.Sholeh Iskandar No.10 \\
\hline 3 & McDonald's Hero Pajajaran & Jl.Padjajaran No.24 \\
\hline 4 & McDonald's Sukahati Cibinong & Jl.Raya Cibinong No.13
\end{tabular}

Sumber : Wikipedia.org 12-07-2017

Tabel 1.1.2 menunjukan sebuah lokasi pada restoran McDonald's yang berada di Kota Bogor dan perkembangannya juga begitu signifikan dengan adanya beberapa cabang restoran yang di buka oleh McDonald's. Sedangkan pada table 1.1.3 menunjukan lokasi restoran KFC dengan melihat beberapa gerai dan cabang yang dibuka oleh KFC yang terdapat di Kota Bogor dan juga sekitarnya. Tidak kalah berkembang dengan restoran McDonald's.

Tabel 1.1.3

Daftar nama Restoran KFC se-kota Bogor

\begin{tabular}{ccc}
\hline No & Cabang Restoran & Lokasi \\
\hline 1 & KFC Parung & Jl. Raya Parung, Parung Plaza \\
\hline 2 & KFC Puncak & Jl. Raya Puncak \\
\hline 3 & KFC Siliwangi & Jl. Siliwangi No. 123 \\
\hline 5 & KFC Juanda & Jl. Ir H Juanda No. 68 \\
\hline 6 & KFC Padjajaran & Jl. Raya Padjajaran No.8 \\
\hline
\end{tabular}

Sumber : https://www.mcdonalds.co.id 
McDonald's merupakan salah satu dari sekian banyak restoran asing yang berhasil memasuki pasar di Indonesia. Dengan budaya yang beragam di Indonesia dengan keberagaman pola perilaku dan kebiasaan yang berbeda pula, McDonald's mampu memenuhi kebutuhan yang ada pada negara Indonesia. Karena, ada budaya asing yang tidak dapat diterima Indonesia dan ada juga yang dapat diterima masyarakat Indonesia. Dalam pemasaran Internasional ada beberapa budaya dalam kebiasan-kebiasan berbisnis dan semua pembisnis yang ingin melakukan pemasaran secara internasional harus menerapkannya seperti yang dilakukan oleh McDonald's. Budaya tersebut adalah budaya imperatif, budaya adiafora, budaya eksklusif.

Budaya imperatif merupakan suatu kebiasan, harapan bisnis yang dapat disesuaikan dengan negara tersebut. Contohnya menu makanan yang ada di McDonald's yang berlokasi di California jelas saja berbeda dengan di Indonesia. Di California hanya menyediakan hamburger, minuman bersoda dan Ice cream. Sedangkan di Indonesia tidak bisa seperti itu. Harus ada menu nasi yang disediakan oleh McDonald's karena makanan pokok khas masyarakat Indonesia adalah nasi. Hal ini jelas saja menjadi keputusan dalam pembelian produk McDonald's karena kebiasaan atau pola kita sebagai orang Indonesia yang harus mengkonsumsi nasi sebagai makanan pokok. Berbeda dengan orang asing yang hanya mengkonsumsi daging dan sayur. (Kristanto 2011).

Budaya Adiafora berkaitan dengan perilaku atau kebiasaan dimana budaya-budaya orang asing diharapkan untuk menyesuaikan atau berpartisipasi dalam budaya penduduk setempat namun, tidak harus dilakukan. Jika dilakukan akan lebih baik namun, jika tidak dilakukan juga tidak berakibat buruk. Misalnya, menu McDonald's di California ditambahkan Hamburger dengan daging ikan salmon mentah dan minuman dengan mengandung soda yang tinggi. Sebenarnya Indonesia pun dapat menambahkan menu seperti itu namun, kita lihat dari sisi lidah orang Indonesia. Masyarakat Indonesia lebih menyukai masakan yang langsung matang dan tidak menyukai minuman dengan indikasi soda yang terlalu tinggi karena tidak baik untuk kesehatan. Ini juga menjadi pengaruh dalam keputusan pembelian menu di McDonald's. Karena orang Indonesia mengkonsumsi untuk kesehatan bukan untuk memperburuk kesehatan dengan meminum air soda yang idikasinya sangat tinggi tidak seperti orang asing yang mampu meminum alkohol ataupun soda dengan kadar yang relative tinggi (Kristanto 2011).

Budaya Eksklusif merupakan pola perilaku yang khusus untuk penduduk setempat dan terlarang bagi orang-orang asing. McDonald's yang berada di daerah korea misalnya. Mayoritas orang korea sangat menyukai segala hal yang berbau babi namun, di Indonesia hal ini dilarang keras. Mayoritas orang Indonesia beragama Muslim dan mengharamkan hal tersebut. Maka, restoran yang masuk ke Indonesia harus bersetifikat halal terlebih dahulu sebelum bersaing di pasar internasional Indonesia. Sebenarnya ada masyarakat Indonesia yang menyukai daging babi dan mungkin akan setuju dengan tambahan menu pada McDonald's namun, orang yang beragama muslim akan sangat keberatan dengan hal ini.(Kristanto 2011).

Secara garis besar, budaya tersebut harus diterapkan dengan baik untuk memenangkan negosiasi di pasar internasional. Apabila, McDonald's mengikuti keseluruhan menu yang sedang berkembang di negara lain namun tidak sesuai dengan negara Indonesia, alhasil McDonal's akan kehilangan pangsa pasar mereka. Hal ini juga berujung dengan keputusan pembelian yang akan di lakukan oleh masyarakat Indonesia. Apabila, mereka merasa makanan yang ada di McDonald's tidak sesuai dengan harapan ataupun ekspetasi mereka, mereka tidak akan mengambil keputusan pembelian pada produk McDonald's.

Menurut penelitian Bilondatu (2013), pemasaran sangat berperan bagi keberhasilan perusahaan yang digunakan sebagai alat untuk mempengaruhi konsumen khususnya dalam melakukan pembelian suatu produk. Motivasi merupakan sebab, tujuan, atau pendorong, dengan kata lain tujuan seseorang itulah sebenarnya yang menjadi penggerak utama baginya berusaha keras untuk mencapai sesuatu. Persepsi adalah suatu proses tentang petunjuk-petunjuk indrawi dan pengalaman masa lampau yang relevan. Kepercayaan adalah keyakinan satu pihak mengenai maksud dan perilaku kepada pihak yang lainnya. 
Berdasarkan hasil wawancara yang dilakukan dengan sepuluh konsumen yang berstatus mahasiswa dikatakan beberapa hal yang berkaitan dengan keputusan pembelian pada objek McDonald's, mereka mengatakan bahwa memiliki menu yang beragam yang tentu saja disukai konsumen, namun menu-menu ini masih dipengaruhi oleh budaya asing yang mengajarkan konsumen untuk lebih menyukai produk asing yang berupa makanan yang ada di restoran McDonald's. Pernah beberapa waktu yang lalu McDonald's mengeluarkan menu berupa burger rendang dan ayam kremes dengan sambal terasi yang menjukan dapat menyesuaikan diri disuatu negara seperti Indonesia, yang ternyata tidak bertahan lama karena para konsumen lebih menyukai menu yang biasa di restoran tersebut yang mengandung unsur budaya asing daripada cita rasa atau makanan khas Indonesia sendiri dan seharusnya McDonald's lebih berusaha menyesuaikan diri dengan baik bukan hanya dengan menyediakan nasi saja. McDonald's sendiri masih dominan dengan minuman bersoda yang bukan menjadi kebiasaan orang Indonesia mengkonsumsi soda. Semua makanan yang ada disana selalu dikombinasikan dengan minuman bersoda. Sehingga, pada intinya McDonald's memiliki makanan berupa junk food yang tidak baik untuk kesehatan.

Tujuan penelitian ini antara lain :

1. Untuk mengetahui seberapa besar pengaruh budaya imperatif terhadap keputusan pembelian produk internasional McDonald's.

2. Untuk mengetahui seberapa besar pengaruh budaya adiafora terhadap keputusan pembelian produk internasional McDonald's.

3. Untuk mengetahui seberapa besar pengaruh budaya eksklusif terhadap keputusan pembelian produk internasional McDonald's.

4. Untuk mengetahui seberapa besar pengaruh budaya imperatif, budaya adiafora dan, budaya eksklusif terhadap keputusan pembelian produk internasional McDonald's.

\section{Tinjauan Pustaka}

\section{Keputusan Pembelian}

Proses pengambilan keputusan yang rumit sering melibatkan beberapa keputusan. Suatu keputusan (decision) melibatkan pilihan diantara dua atau lebih alternative tindakan (atau perilaku). Keputusan mensyaratkan pilihan di antara beberapa perilaku yang berbeda (Nugroho, 2008). Aspek dilibatkan dalam pengambilan keputusan konsumen, termasuk pengetahuan, arti, kepercayaan yang diaktifkan dari ingatan serta proses perhatian dan pemahaman yang terlibat dalam penerjemahan informasi baru di lingkungan. Akan tetapi, inti dari pengambilan keputusan konsumen (consumer decision making) adalah proses pengintegrasian yang mengkombinasikan pengetahuan untuk mengevaluasi dua atau lebih perilaku alternative, dan memilih salah satu diantaranya. Hasil dari proses pengintegrasian ini adalah suatu pilihan (choice) yang disajikan secara kognitif sebagai keinginan berperilaku (Nugroho, 2008).

Menurut Kotler dan Amstrong (2008) mengemukakan bahwa: "Keputusan pembelian adalah tahap proses keputusan dimana konsumen secara actual melakukan pembelian produk". Dari pernyataan dapat dilihat bahwa keputusan pembelian merupakan untuk melakukan suatu pembelian, pemasar harus dapat mengubah sikap atau membuat konsumen agar bertindak.

Dari definisi menurut para ahli dapat disimpulkan bahwa keputusan pembelian adalah tindakan konsumen yang proses pengintegrasian yang mengkombinasikan pengetahuan untuk mengevaluasi dua atau lebih perilaku alternative, dan memilih salah satu diantaranya.

\section{Budaya Imperatif}

Budaya impeatif adalah kebiasaan dan pengharapan bisnis yang harus dipenuhi dan disesuaikan dengan,atau dihindari apabila seseorang menginginkan suatu hubungan yang berhasil. Graham dan Cateora (2007). Para pengusaha yang sukses mengenal kata guanxi dalam bahasa Cina, kata ningen kankei dalam bahasa Jepang, atau kata compadre dalam bahasa Amerika Latin. 
Semua kata tersebut merujuk pada persahabatan, hubungan manusia, atau pencapaian suatu tingkat kepercayaan. Mereka juga tahu bahwa tidak ada yang dapat menggantikan penjalinan persahabatan di beberapa budaya sebelum negosiasi bisnis yang efektif dapat dimulai.

Diskusi informal, sesuatu yang menghibur, teman-teman yang mutual, kontak, dan sekedar menghabiskan waktu bersama orang lain merupakan cara-cara guanxi, ningen kankei, compadre, dan hubungan-hubungan penuh kepercayaann yang lain dibina. Dalam budaya dimana persahabatan merupakan kunci menuju keberhasilan, pengusaha tidak boleh meremehkan waktu yang dibutuhkan perkembangannya. Seperti Indonesia yang juga merujuk persahabatan dengan negara-negara lain untuk perkemabangan negara tesebut dan negara Indonesia sendiri. Persahabatan memotivasi agen-agen local untuk melakukan lebih banyak penjualan, dan persahabatan membantu membangun hubungan yang tepat dengan para pengguna akhir, yang menghasilkan lebih banyak penjualan untuk periode yang lebih lama. Tentu saja layanan purna jual, harga, dan produk haruslah kompetitif, tetapi pemasar yang telah membangun persahabatan tersebut lebih maju. Membangun persahabatan merupakan suatu imperatif dalam banyak budaya dan di banyak negara pula. Apabila persahabatan tidak dibangun dengan cara menyesuaikan, pemasar mengambil resiko tidak mendapatkan kepercayaan dan penerimaan yang merupakan prasyarat budaya yang mendasar untuk mengembangkan dan memelihara hubungan bisnis yang efektif.

Pentingnya membangun suatu persahabatan tidak bias ditekan secara berlebihan, terutama di negara-negara di mana hubungan keluarga sangatlah dekat. Di Cina misalnya, orang luar berada di paling bagus tempat kelima dalam urutan kepentingan ketika memutuskan dengan siapa mereka harus melakukan bisnis. Keluarga menempati urutan pertama, kemudia keluarga besar, kemudian para tetangga dari kampong halaman seseorang, kemudian bekas teman sekelas, dan kemudian, dengan enggan, orang-orang asing dan hanya akan melakukan hubungan bisnis dengan orang asing setelah terbinanya hubungan yang penuh kepercayaan.

Menurut Graham dan Cateora (2007) dalam beberapa budaya, kelakuan seseorang lebih penting bila dibandingkan dalam budaya-budaya yang lain. Sebagai contoh, barangkali tidak pernah pantas untuk kehilangan kesabaran anda, menaikan suara anda, atau meluruskan kesalahan seseorang di depan umum, tidak perduli seberapa frustasinya situasi tersebut. Dalam beberapa budaya, perilaku seperti ini hanya akan membuat seseorang dianggap tidak sopan, tetapi dalam budaya-budaya Asia, adalah imperatif untuk tidak membuat rekan bisnis anda kehilangan muka. Di Cina, menaikan suara anda, meneriaki orang di depan umum, atau mengoreksi seseorang di depan teman-temannya akan membuat seseorang tersebut kehilangan muka.

Faktor yang menyulitkan dalam kesadaran budaya adalah apa yang mungkin imperatif umtuk dihindari dalam suatu budaya merupakan sesuatu yang imperatif untuk di lakukan dalam budaya lain. Di Jepang misalnya, kontak mata yang diperpanjang dianggap ofensif, dan seharusnya dihindari. Namun, adalah penting untuk melakukan kontak mata yang kuat dengan eksekutifeksekutif Arab dan Amerika Latin, atau anda akan di anggap sebagai orang yang suka mengelak dan tidak dapat di percaya.

Ada 4 (empat) indikator yang harus diperhatikan dalam menjalankan kebiasaan berbisnis internasional menurut Graham dan Cateora:

1. Kebiasaan

2. Pola Pikir

3. Perilaku

4. Kehidupan Material

\section{Budaya Adiafora}

Budaya adiafora adalah perilaku atau kebiasaan di mana orang-orang asing boleh menyesuaikan diri atau berpartisipasi, tetapi tidak diharuskan. Dengan kata lain, mengikuti kebiasaan yang sedang didiskusikan bukan merupakan sesuatu yang penting, tetapi diperbolehkan Graham dan 
Cateora (2007). Mayoritas kebiasaan masuk dalam kategori ini. Seseorang tidak perlu memberi salam kepada orang lain dengan mencium kening (sebuah kebiasaan di beberapa negara), menyantap makanan yang tidak bias diterima oleh system pencernaan (selama penolakan di lakukan dengan ramah), atau meminum minuman beralcohol ( apabila karena alasan kesehatan, pribadi, atau religius ). Disisi lain, suatu upaya simbolis untuk berpartisipasi dalam opsi-opsi seperti itu tidak hanya bias diterima, tetapi juga dapat membantu membangun hubungan. Upaya tersebut menunjukan bahwa pemasar telah mempelajari budaya tersebut. Orang jepang tidak mengharap orang barat untuk membungkuk dan memahami ritual membungkuk diantara orangorang jepang, namun tundukan simbolis mengindikasikan minat, dan sedikit sensitivitas terhadap budaya Jepang yang diakui sebagai isyarat maksud baik. Seperti di Indonesia pula, tidak mengharap orang asing mengkonsumsi nasi namun, apabila orang asing ingin mencoba makanan pokok dari Indonesia tersebut, tidak masalah.

Budaya adiafora disuatu negara mungkin merupakan budaya yang imperatif di negara yang lain. Sebagai contoh, di beberapa budaya seseorang dapat menerima atau menolak tawaran minum dengan bijaksana dan dengan sopan, sementara di kasus-kasus yang lain tawaran minum merupakan sebuah ritual khusus, dan penolakan dianggap suatu penghinaan. Di Republik Cheska, minuman beralkohol peningkat selera makan atau sopi (minuman keras) manis lain yang diberikan diawal rapat bisnis, meskipun dipagi hari, merupakan suatu cara untuk membangun maksud baik dan kepercayaan. Minuman beralkohol ini merupakan sebuah tanda bahwa anda disambut sebagai seorang teman. Adalah imperatif apabila anda menerima tawaran tersebut, kecuali anda memberikan kejelasan kepada rekan bisnis Cheska anda bahwa penolakan tersebut dikarenakan kesehatan ataupun agama. Karena tidak semua orang bahkan negara dapat menerima tawaran minum alcohol seperti Indonesia yang sangat dilarang keras. Negosiasinegosiasi bisnis orang China sering melibatkan jamuan makan resmi, dimana sejumlah besar alcohol dikonsumsi dalam rangkaian toast yang tidak ada habisnya. Adalah imperatif bahwa anda berpartisipasi dalam toast tersebut dengan gelas yang berisi minuman dinaikan, tetapi untuk meminumnya adalah sebuah opsi. Apabila Indonesia menjadi rekan bisnis negara Arab maka akan menawarkan kopi sebagai bagian dari ritual penting dalam pembangunan suatu tingkat persahabatan dan kepercayaan; anda harus menerimanya meskipun anda hanya melakukan sesapan seremonial. Budaya adiafora adalah kebiasaan-kebiasaan yang tampak sangat berbeda, dan maka dari itu terlihat lebih jelas. Acap kali, yang lebih penting adalah pemenuhan terhadap imperatif dan eksklusif yang tidak begitu jelas.

Ada 3 (tiga) indikator yang harus diperhatikan dalam menjalankan kebiasaan berbisnis internasional menurut Graham dan Cateora:

1. Distribusi

2. Promosi

3. Interaksi social

\section{Budaya Eksklusif}

Budaya eksklusif adalah kebiasaan-kebiasaan atau pola-pola perilaku yang di peruntukan secara eksklusif untuk orang-orang local, dan untuk menghalangi orang-orang asing Graham dan Cateora (2007). Sebagai contoh, seorang kristiani berusaha bertindak seperti seorang muslin dianggap menjijikan bagi seorang pengikut Nabi Muhammad. Yang sama ofensifnya adalah seorang asing yang berkritik atasu berkelakar tentang politik, adat istiadat, dan keganjilan (yang terasa asing bagi orang asing tersebut) suatu negara, walaupun orang-orang local mungkin mengkritik persoalan-persoalan serupa diantara mereka sendiri. Terkandung kebenaran dalam pepatah kuno, " Aku akan mengutuk saudaraku, tetapi bila kau mengutuk dia, kau akan mendapat perlawanan". Beberapa kebiasaan budaya diperuntukan secara eksklusif untuk orang-orang local, tetapi orang asing harus menahan diri dengan hati-hati dari berpartisipasi dalam kebiasankebiasaan tersebut. 
Manajer-manajer asing harus cukup cerdik untuk mengetahui kapan mereka berhadapan dengan sebuah budaya imperatif, budaya adiafora dan budaya eksklusif dan mempunyai adaptabilitas untuk merespons setiap kebiasaan. Tidak terdapat banyak imperatif atau eksklusif, tetapi sebagian besar perilaku ofensif merupakan akibat dari ketidaktahuan akan kebiasaan-kebiasaan tersebut. Tidak perlu merasa dihantui bahwa kita akan melakukan kesalahan social. Sebagioan besar pengusaha yang bijaksana akan memberi kelonggaran untuk kesalahan yang kadang kala terjadi.

Ada 2 (dua) indikator yang harus diperhatikan dalam menjalankan kebiasaan berbisnis internasional menurut Graham dan Cateora :

1. Agama dan kepercayaan

2. Etika dan moral

\section{Penelitian Terdahulu}

Tabel 2.4.1

Penelitian Terdahulu

\begin{tabular}{|c|c|c|c|c|}
\hline Referensi & Judul & Tujuan Penelitian & $\begin{array}{c}\text { Metode } \\
\text { Penelitian }\end{array}$ & Hasil \\
\hline $\begin{array}{l}\text { Puspitarini } \\
\text { (2013) }\end{array}$ & $\begin{array}{l}\text { Pengaruh Faktor } \\
\text { Kebudayaan, } \\
\text { Sosial, Pribadi, Dan } \\
\text { Psikologi terhadap } \\
\text { Proses Keputusan } \\
\text { Pembelian Produk } \\
\text { Pizza (Studi Pada } \\
\text { Pizza Hut Cabang } \\
\text { Jalan Jendral } \\
\text { Sudirman No. } 53 \\
\text { Yogyakarta). }\end{array}$ & $\begin{array}{l}\text { Untuk mengetahui } \\
\text { pengaruh faktor } \\
\text { kebudayaan, sosial, } \\
\text { pribadi dan psikologi } \\
\text { terhadap proses } \\
\text { keputusan } \\
\text { pembelian produk } \\
\text { pizza baik secara } \\
\text { parsial maupun } \\
\text { secara simultan. }\end{array}$ & $\begin{array}{l}\text { Purposive } \\
\text { sampling }\end{array}$ & $\begin{array}{l}\text { Hasilnya } \\
\text { berpengaruh } \\
\text { positif antara } \\
\text { budaya, sosial, } \\
\text { pribadi dan } \\
\text { psikologis } \\
\text { terhadap } \\
\text { keputusan } \\
\text { pembelian produk } \\
\text { Pizza di } \\
\text { Yogyakarta. }\end{array}$ \\
\hline $\begin{array}{l}\text { Andini } \\
(2012)\end{array}$ & $\begin{array}{l}\text { Analisis faktor- } \\
\text { Faktor Yang } \\
\text { Mempengaruhi } \\
\text { Keputusan } \\
\text { Pembelian Mobil } \\
\text { Hyundai i20 (Studi } \\
\text { Kasus Pada } \\
\text { Konsumen Mobil } \\
\text { Hyundai i20 di } \\
\text { Semarang). }\end{array}$ & $\begin{array}{l}\text { Menguji pengaruh } \\
\text { dari variabel } \\
\text { kualitas, harga, } \\
\text { promosi, kesadaran } \\
\text { merek, citra merek, } \\
\text { kepribadian merek, } \\
\text { dan popularitas } \\
\text { terhadap keputusan } \\
\text { pembelian } \\
\text { konsumen pada } \\
\text { mobil Hyundai i20. }\end{array}$ & $\begin{array}{l}\text { Regresi } \\
\text { Berganda }\end{array}$ & $\begin{array}{l}\text { Hasilnya } \\
\text { berpengaruh } \\
\text { positif terhadap } \\
\text { faktor-faktor yang } \\
\text { mempengaruhi } \\
\text { keputusan } \\
\text { pembelian mobil } \\
\text { Hyundai. }\end{array}$ \\
\hline
\end{tabular}




\begin{tabular}{|c|c|c|c|c|}
\hline $\begin{array}{l}\text { Bodroastuti } \\
\text { (2012) }\end{array}$ & $\begin{array}{l}\text { Pengaruh Faktor } \\
\text { Budaya, Sosial, } \\
\text { Pribadi Dan } \\
\text { Psikologi Terhadap } \\
\text { Perilaku Konsumen } \\
\text { (Studi Pada } \\
\text { Pembelian Rumah } \\
\text { di Perumahan Griya } \\
\text { Utama Banjardowo } \\
\text { Semarang). }\end{array}$ & $\begin{array}{l}\text { Menganalisis } \\
\text { pengaruh budaya, } \\
\text { sosial, kepribadian } \\
\text { dan psikologi } \\
\text { terhadap perilaku } \\
\text { pelanggan. Populasi } \\
\text { dalam penelitian ini } \\
\text { adalah semua } \\
\text { pelanggan yang } \\
\text { telah membeli } \\
\text { rumah di Griya } \\
\text { Utama Perumahan } \\
\text { Banjardowo. }\end{array}$ & $\begin{array}{l}\text { Regresi } \\
\text { linier } \\
\text { berganda. }\end{array}$ & $\begin{array}{l}\text { Hasilnya } \\
\text { berpengaruh } \\
\text { positif antara } \\
\text { budaya, sosial, } \\
\text { pribadi dan } \\
\text { psikologis } \\
\text { terhadap } \\
\text { keputusan } \\
\text { pembelian Rumah } \\
\text { di Perumahan } \\
\text { Griya Utama } \\
\text { Banjardowo } \\
\text { Semarang. }\end{array}$ \\
\hline
\end{tabular}

\section{Posisi Penelitian}

Tabel 2.5.1

Posisi Penelitian 1

Pengaruh Faktor Kebudayaan, Sosial, Pribadi, Dan Psikologi : $\quad$ terhadap Proses Keputusan Pembelian Produk Pizza (Studi Pada Pizza Hut Cabang Jalan Jendral Sudirman No. 53 Yogyakarta).

Nama $\quad$ : Dian Puspitarini (2013)

Tujuan : Untuk mengetahui pengaruh faktor kebudayaan, sosial, pribadi dan psikologi terhadap proses keputusan pembelian produk pizza baik secara parsial maupun secara simultan.

Populasi dalam penelitian ini adalah semua pengunjung dan

$\begin{array}{lll}\text { Sampel dan } & \text { Populasi dalam penelitian ini adalah semua pengunjung dan } \\ \text { Populasi } & \text { pembeli produk pizza di restoran siap saji Pizza hut cabang Jl. } \\ \text { Jendral Sudriman No. } 53 \text { Yogyakarta. Julmlah sampel yang } \\ \text { digunakan pada penelitian ini adalah } 100 \text { responden. }\end{array}$

\begin{tabular}{lll}
\hline Metode & : $\quad$ Purposive sampling \\
Penelitian
\end{tabular}

$\begin{array}{lll}\text { Objek } & \text { : Pizza Hut } \\ \text { Penelitian }\end{array}$




\begin{tabular}{ll}
\hline & Perbedaan penelitian adalah, skripsi ini meneliti tentang \\
kebudayaan secara luas namun bukan dalam lingkup pemasaraan \\
internasional, hanya kebudayaan berdasarkan secara umum saja \\
dan juga meneliti berdasarkan sosial, pribadi dan prikologi untuk \\
menentukan keputusan pembelian pada konsumen tersebut. Dian \\
lebih meneliti ke konsumen itu sendiri dalam artian lebih fokus ke \\
Pensumen dari pada ke lingkungan konsumen itu sendiri. \\
Penelitian $\quad$ Sedangkan saya sendiri, meneliti budaya secara pemasaran \\
internasional bukan budaya secara umumnya, namun lebih sempit \\
dari budaya secara umum. Namun, pada dasarnya unsur \\
budayanya tetap sama seperti budaya secara umum dengan objek \\
penelitian Mc'Donalds.
\end{tabular}

Tabel 2.5.2

Posisi Penelitian 2

\begin{tabular}{|c|c|c|}
\hline Judul & : & $\begin{array}{l}\text { Analisis faktor-Faktor Yang Mempengaruhi Keputusan Pembelian } \\
\text { Mobil Hyundai i20 (Studi Kasus Pada Konsumen Mobil Hyundai i20 } \\
\text { di Semarang). }\end{array}$ \\
\hline Nama & : & Prisca Andini (2012) \\
\hline Tujuan & $:$ & $\begin{array}{l}\text { Menguji pengaruh dari variabel kualitas, harga, promosi, } \\
\text { kesadaran merek, citra merek, kepribadian merek, dan popularitas } \\
\text { terhadap keputusan pembelian konsumen pada mobil Hyundai i20. }\end{array}$ \\
\hline $\begin{array}{l}\text { Sampel dan } \\
\text { Populasi }\end{array}$ & $:$ & $\begin{array}{l}\text { Populasi penelitian ini mengacu pada penduduk di Semarang yang } \\
\text { merupakan konsumen mobil Hyundai i20. Sampel dilakukan } \\
\text { dengan pertimbangan-pertimbangan tertentu dengan } \\
\text { memperhatikan respoden yang dikehendaki untuk memudahkan } \\
\text { penelitian sehingga diambil sampel sebanyak } 100 \text { orang yang } \\
\text { pernah memakai produk Hyundai i20. }\end{array}$ \\
\hline $\begin{array}{l}\text { Metode } \\
\text { Penelitian }\end{array}$ & $:$ & Regresi Berganda \\
\hline $\begin{array}{l}\text { Objek } \\
\text { Penelitian }\end{array}$ & : & Hyundai i20 \\
\hline
\end{tabular}




\begin{tabular}{ll}
\hline & Perbedaan penelitian adalah, skripsi ini menguji pengaruh dari \\
variabel, kualitas, harga, promosi, kesadaran merek, dan \\
popularitas terhadap keputusan pembelian. Andini lebih melihat ke \\
arah dasar produk tersebut, bagaimana konsumen dapat \\
melakukan keputusan pembelian dengan melihat merek dan juga \\
harga yang ditawarkan kepada merek tersebut sehingga terjadilah \\
proses keputusan pembelian kepada konsumen tersebut untuk \\
melakukan pembelian mobil Hyundai i20 di daerah Semarang. \\
Sedangkan saya, meneliti keutusan pembelian dilihat dari segi \\
Pendaya secara internasional. Bagaimana konsumen dapat \\
melakukan suatu keputusan pembelian apabila melihat dari segi \\
budaya suatu negara, karena pada dasarnya beda negara beda \\
pula budaya yang ada pada negara tersebut dan saya meneliti \\
tentang budaya-budaya saja tanpa melihat ke dalam produk \\
tersendiri dengan objek penelitian Mc'Donalds.
\end{tabular}

Tabel 2.5.3

Posisi Penelitian 3

\begin{tabular}{ll}
\hline & Pengaruh Faktor Budaya, Sosial, Pribadi Dan Psikologi Terhadap \\
Judul $\quad$ Perilaku Konsumen (Studi Pada Pembelian Rumah di Perumahan \\
Griya Utama Banjardowo Semarang)
\end{tabular}

Nama $\quad: \quad$ Abdul Ghoni Tri Bodroastuti (2012)

\begin{tabular}{lll}
\hline Tujuan & $\begin{array}{l}\text { Menganalisis pengaruh budaya, sosial, kepribadian dan psikologi } \\
\text { terhadap perilaku pelanggan. Populasi dalam penelitian ini adalah } \\
\text { semua pelanggan yang telah membeli rumah di Griya Utama } \\
\text { Perumahan Banjardowo. }\end{array}$ \\
\hline $\begin{array}{l}\text { Sampel dan } \\
\text { Populasi }\end{array}$ & $\begin{array}{l}\text { Adapun yang dijadukan sebagai populasi adalah seluruh } \\
\text { konsumen yang telah membeli rumah di Perumahan Griya Utama } \\
\text { Bandawarjo sejak tahun 2008-2011 yaitu sebanyak 234 unit rumah } \\
\text { yang dihuni yang mencakup seluruh tipe rumah yang dibangun di } \\
\text { setiap cluster. Jumlah sampel dalam penelitian ini menggunakan } \\
\text { rumus slovin dengan jumlah respoden sebanyak 74 responden. }\end{array}$ \\
\hline $\begin{array}{l}\text { Metode } \\
\text { Penelitian }\end{array}$ & $: \quad$ Regresi linier berganda. \\
\hline $\begin{array}{l}\text { Objek } \\
\text { Penelitian }\end{array}$ & Griya Utama Banjardowo Semarang. \\
\hline
\end{tabular}


Perbedaan penelitian adalah, skripsi ini meneliti tentang kebudayaan secara luas namun bukan dalam lingkup pemasaraan internasional, hanya kebudayaan berdasarkan secara umum saja dan juga meneliti berdasarkan sosial, pribadi dan prikologi untuk menentukan keputusan pembelian pada konsumen tersebut. Abdul Perbedaan : lebih meneliti ke konsumen itu sendiri dalam artian lebih fokus ke Penelitian : konsumen dari pada ke lingkungan konsumen itu sendiri. Sedangkan saya sendiri, meneliti budaya secara pemasaran internasional bukan budaya secara umumnya, namun lebih sempit dari budaya secara umum. Namun, pada dasarnya unsur budayanya tetap sama seperti budaya secara umum dengan objek penelitian Mc'Donalds.

\section{Metode}

Variabel penelitian adalah suatu atribut atau sifat dari orang, obyek atau kegiatan yang memiliki variasi tertentu yang ditetapkan oleh peneliti untuk dipelajari dan ditarik kesimpulannya (Sugiyono, 2007). Berkaitan dengan penelitian ini, variabel penelitian yang terdiri dari variabel dependen dan variabel independen diuraikan sebagai berikut :

\section{Variabel Dependen}

Variabel dependen adalah variabel yang menjadi pusat perhatian peneliti (Ferdinand, 2006). Variabel dependen yaitu variabel yang nilainya dipengaruhi oleh variabel independen. Yang dijadikan sebagai variabel dependen dalam penelitian ini adalah keputusan pembelian (Y).

\section{Variabel Independen}

Variabel independen adalah variabel yang mempengaruhi variabel dependen, baik yang pengaruhnya positif maupun yang pengaruhnya negatif (Ferdinand, 2006). Variabel independen dalam penelitian ini terdiri dari :

a. Budaya Imperatif $\left(X_{1}\right)$

b. Budaya Adiafora $\left(X_{2}\right)$

c. Budaya Eksklusif $\left(X_{3}\right)$

Operasional variabel dapat didasarkan pada satu atau lebih referensi yang disertai dengan alasan penggunaan definisi tersebut. Variabel penelitian harus dapat diukur menurut skala ukuran yang lazim digunakan. Oleh karena itu, untuk memberikan gambaran yang lebih jelas tentang variabel penelitian, maka disajikan tabel sebagai berikut:

\section{Tabel 3.2.1.1}

Opersional Variabel

\begin{tabular}{clll}
\hline Variabel & \multicolumn{1}{c}{ Definisi } & \multicolumn{1}{c}{ Indikator } \\
\hline & $\begin{array}{l}\text { Budaya impeatif adalah kebiasaan } \\
\text { dan pengharapan bisnis yang harus }\end{array}$ & 1. Kebiasaan & \\
Budaya & dipenuhi dan disesuaikan & 2. Pola Pikir & Ordinal \\
Imperatif & dengan,atau dihindari apabila & 3. Perilaku & Ordinal \\
(X1) & $\begin{array}{l}\text { seseorang menginginkan suatu } \\
\text { hubungan yang berhasil. (Graham }\end{array}$ & 4. Kehidupan Material & - Ordinal \\
& dan Cateora (2007)).
\end{tabular}




\begin{tabular}{|c|c|c|c|}
\hline $\begin{array}{l}\text { Budaya } \\
\text { Adiafora } \\
\text { (X2) }\end{array}$ & $\begin{array}{l}\text { Budaya adiafora adalah perilaku } \\
\text { atau kebiasaan di mana orang- } \\
\text { orang asing boleh menyesuaikan } \\
\text { diri atau berpartisipasi, tetapi tidak } \\
\text { diharuskan. Dengan kata lain, } \\
\text { mengikuti kebiasaan yang sedang } \\
\text { didiskusikan bukan merupakan } \\
\text { sesuatu yang penting, tetapi } \\
\text { diperbolehkan (Graham dan } \\
\text { Cateora (2007)). }\end{array}$ & $\begin{array}{l}\text { 1. Distribusi } \\
\text { 2. Promosi } \\
\text { 3. Interaksi Sosial }\end{array}$ & $\begin{array}{ll}\text { - } & \text { Ordinal } \\
\text { - Ordinal } \\
\text { - }\end{array}$ \\
\hline $\begin{array}{l}\text { Budaya } \\
\text { Eksklusif } \\
\text { (X3) }\end{array}$ & $\begin{array}{l}\text { Budaya eksklusif adalah kebiasaan- } \\
\text { kebiasaan atau pola-pola perilaku } \\
\text { yang di peruntukan secara eksklusif } \\
\text { untuk orang-orang local, dan untuk } \\
\text { menghalangi orang-orang asing. } \\
\text { (Graham dan Cateora (2007)). }\end{array}$ & $\begin{array}{l}\text { 1. Agama dan } \\
\text { kepercayaan } \\
\text { 2. Etika dan moral }\end{array}$ & $\begin{array}{l}\text { - Ordinal } \\
\text { - Ordinal }\end{array}$ \\
\hline $\begin{array}{l}\text { Keputusan } \\
\text { Pembelian } \\
\text { (Y) }\end{array}$ & $\begin{array}{l}\text { Proses pengambilan keputusan } \\
\text { yang rumit sering melibatkan } \\
\text { beberapa keputusan. Suatu } \\
\text { keputusan (decision) melibatkan } \\
\text { pilihan diantara dua atau lebih } \\
\text { alternative tindakan (atau perilaku). } \\
\text { Keputusan mensyaratkan pilihan di } \\
\text { antara beberapa perilaku yang } \\
\text { berbeda (Nugroho,2008). }\end{array}$ & $\begin{array}{l}\text { 1. Tujuan dalam } \\
\text { membeli sebuah produk } \\
\text { 2. Pemrosesan informasi } \\
\text { sampai pada pemilihan } \\
\text { merek } \\
\text { 3. Memberikan } \\
\text { rekomendasi pada orang } \\
\text { lain } \\
\text { 4. Melakukan pembelian } \\
\text { ulang }\end{array}$ & $\begin{array}{l}\text { - Ordinal } \\
\text { - Ordinal } \\
\text { - Ordinal } \\
\text { - Ordinal }\end{array}$ \\
\hline
\end{tabular}

Skala pengukuran yang digunakan untuk mengukur indikator-indikator pada variabel dependen dan variabel independen tersebut adalah dengan menggunakan Skala Likert (1-5) yang mempunyai lima tingkat preferensi jawaban masing-masing mempunyai skor 1-5 dengan rincian sebagai berikut:

1. = Sangat Tidak Setuju (STS)

2. = Tidak Setuju (TS)

3. $=\operatorname{Netral}(\mathrm{N})$

4. $=$ Setuju (S)

5. = Sangat Setuju (SS)

Sampel merupakan bagian dari jumlah dan karakteristik yang dimiliki oleh populasi tersebut (Sugiyono:2007). Jadi sampel merupakan bagian dari populasi yang diambil melalui cara-cara tertentu yang juga memiliki karakteristik tertentu, jelas dan lengkap yang dianggap bisa mewakili populasi. Ukuran populasi penelitian ini tidak teridentifikasi, maka untuk menentukan ukuran sampel penelitian dari populasi tersebut dapat digunakan rumus roscoe. Roscoe (Sugiyono, 2010 : 129) untuk penelitian yang populasinya tidak diketahui maka jumlah sampel lebih dari 30 dan lebih kecil dari 500 dianggap sudah mewakili populasi tersebut. Dengan rumus $10 \times$ (variabel independent + variabel dependent).

Berdasarkan perhitugan dari Roscoe maka sampel dalam penelitian ini yaitu :

Indikator $\mathrm{X} 1=4$, indikator $\mathrm{X} 2=3$, indikator $\mathrm{X} 3=2$, indikator $\mathrm{Y}=4$ totalnya adalah 13 . 


$$
\begin{aligned}
& =10 \times(4+3+2+4) \\
& =10 \times 13 \\
& =130
\end{aligned}
$$

Melalui dasar pertimbangan dari perhitungan sampel menurut roscoe maka diputuskan untuk mengambil sampel sebanyak 100 responden hal ini dikarenakan meningat keterbatasan waktu maka penelitian diambil 100 orang responden seperti metode slovin.

Dari perhitungan diatas, maka dapat diketahui bahwa jumlah sampel yang digunakan dalam penelitian ini sebanyak 100 orang responden. Pada penelitian ini menggunakan pendekatan non probability sampling yaitu teknik sampling yang tidak memberikan kesempatan sama bagi setiap unsur atau anggota populasi untuk dijadikan sampel (Sugiyono:2007). Sedangkan penentuan pengambilan jumlah responden (sampel) dilakukan melalui teknik purposive sampling, yaitu peneliti memilih siapa saja anggota populasi yang secara kebetulan bertemu dengan peneliti dianggap dapat memberikan informasi yang diperlukan.

Jadi sampel diambil dengan cara memilih elemen-elemen untuk menjadi anggota sampel yang ditentukan secara subyektif sekali. Semua sampel diperoleh dari konsumen McDonald's yang ada di wilayah Bogor.

\section{Hasil dan Pembahasan Profil Responden}

Untuk mengetahui gambaran pengisian kuisioner yang dilakukan oleh 100 responden yang sebenarnya berikut ditampilkan data profil reponden yang terdiri dari dekripsi responden berdasarkan jenis kelamin, deskripsi responden berdasarkan status, deskripsi responden berdasarkan umur, deskripsi responden berdasarkan kunjungan ke McDonald's, deskripsi responden berdasarkan alas an mengunjungi McDonald's, deskripsi responden berdasarkan orang yang mempengaruhi dan deskripsi responden berdasarkan pendapat mengenai makanan yang ada di McDonald's, berikut data yang dimaksud :

Tabel 4.1.1

Responden Berdasarkan Jenis kelamin

\begin{tabular}{llcccc}
\hline & & Frequency & Percent & $\begin{array}{c}\text { Valid } \\
\text { Percent }\end{array}$ & Cumulative Percent \\
\hline \multirow{2}{*}{ Valid } & Laki-Laki & 44 & 44.0 & 44.0 & 44.0 \\
\cline { 2 - 6 } & Perempuan & 56 & 56.0 & 56.0 & 100.0 \\
\cline { 2 - 6 } & Total & 100 & 100.0 & 100.0 & \\
\hline
\end{tabular}

Sumber: Data hasil pengolahan SPSS,2017

Berdasarkan table 4.1.1, menunjukan hasil responden yang telah mengisi kuisioner dimana terdapat responden laki-laki yang dengan jumlah 44 (44\%) dan responden perempuan yang dengan jumlah 56 (56\%). Dengan demikian hasil tersebut menunjukan bahwa responden perempuan lebih dominan dibandingkan dengan responden laki-laki.

\begin{tabular}{|c|c|c|c|c|c|}
\hline & & Frequency & Percent & $\begin{array}{c}\text { Valid } \\
\text { Percent }\end{array}$ & Cumulative Percent \\
\hline Valid & Menikah & 7 & 7.0 & 7.0 & 7.0 \\
\hline
\end{tabular}

Tabel 4.1.2

Responden Berdasarkan Status 


\begin{tabular}{lcccc}
\hline Belum Menikah & 91 & 91.0 & 91.0 & 98.0 \\
\hline Berpisah & 2 & 2.0 & 2.0 & 100.0 \\
\hline Total & 100 & 100.0 & 100.0 & \\
\hline
\end{tabular}

Sumber: Data hasil pengolahan SPSS,2017

Berdasarkan table 4.1.2, menunjukan hasil responden yang telah mengisi kuisioner dimana status responden menikah dengan jumlah 7 (7\%), status belum menikah dengan jumlah 91 (91\%) dan status berpisah dengan jumlah 2 (2\%). Dengan demikian hasil tersebut menunjukan bahwa status responen belum menikah lebih dominan dibandingkan dengan menikah dan berpisah.

Tabel 4.1.3

Responden Berdasarkan Umur

\begin{tabular}{cccccc}
\hline & Frequency & Percent & $\begin{array}{c}\text { Valid } \\
\text { Percent }\end{array}$ & Cumulative Percent \\
\hline \multirow{5}{*}{ Valid } & $15-20$ Tahun & 11 & 11.0 & 11.0 & 11.0 \\
\cline { 2 - 6 } & $>21-25$ Tahun & 81 & 81.0 & 81.0 & 92.0 \\
\cline { 2 - 6 }$>26-30$ Tahun & 3 & 3.0 & 3.0 & 95.0 \\
\cline { 2 - 6 }$>31-35$ Tahun & 2 & 2.0 & 2.0 & 97.0 \\
\cline { 2 - 5 }$>$ >40 Tahun & 3 & 3.0 & 3.0 & 100.0 \\
\hline Total & 100 & 100.0 & 100.0 & \\
\hline
\end{tabular}

Sumber: Data hasil pengolahan SPSS,2017

Berdasarkan table 4.1.3, menunjukan hasil responden yang telah mengisi kuisioner dimana usia responden dari 15-20 tahun dengan jumlah $11(11 \%)$, usia >21-25 tahun dengan jumlah 81 (81\%), usia >26-30 tahun dengan jumlah $3(3 \%)$, usia $>31-35$ tahun dengan jumlah $2(2 \%)$ dan usia $>40$ tahun dengan jumlah $3(3 \%)$. Dengan demikian hasil tersebut menunjukan bahwa usia responden $>21-25$ tahun lebih dominan dibandingan dengan usia 15-20 tahun, usia >26-30 tahun, usia $>31-$ 35 tahun dan usia $>40$ tahun.

Tabel 4.1.4

Responden Berdasarkan Pekerjaan

\begin{tabular}{llcccc}
\hline & & Frequency & Percent & $\begin{array}{c}\text { Valid } \\
\text { Percent }\end{array}$ & Cumulative Percent \\
\hline \multirow{3}{*}{ Valid } & Karyawan & 22 & 22.0 & 22.0 & 22.0 \\
\cline { 2 - 6 } & Pelajar & 4 & 4.0 & 4.0 & 26.0 \\
\cline { 2 - 6 } & Mahasiswa & 68 & 68.0 & 68.0 & 94.0 \\
\cline { 2 - 6 } & Profesional & 6 & 6.0 & 6.0 & 100.0 \\
\cline { 2 - 5 } & Total & 100 & 100.0 & 100.0 & \\
\hline
\end{tabular}

Sumber: Data hasil pengolahan SPSS,2017

Berdasarkan table 4.1.4, menunjukan hasil responden yang telah mengisi kusioner dimana perkerjaan responden sebagai karyawan dengan jumlah 22 (22\%), sebagai pelajar dengan nilai $4(4 \%)$, sebagai mahasiswa dengan jumlah $68(68 \%)$, sebagai professional dengan jumlah 6 $(6 \%)$. Dengan demikian hasil teresebut menunjukan bahwa pekerjaan responden sebagai mahasiswa lebih dominan dibandingkan dengan sebagai karyawan, pelajar dan professional. 
Tabel 4.1 .5

Responden Berdasarkan Kunjungan ke McDonald's

\begin{tabular}{llcccc}
\hline & & Frequency & Percent & $\begin{array}{c}\text { Valid } \\
\text { Percent }\end{array}$ & Cumulative Percent \\
\hline \multirow{3}{*}{ Valid } & Sendirian & 13 & 13.0 & 13.0 & 13.0 \\
\cline { 2 - 6 } & Teman & 76 & 76.0 & 76.0 & 89.0 \\
\cline { 2 - 6 } Keluarga & 8 & 8.0 & 8.0 & 97.0 \\
\cline { 2 - 6 } & Lainna & 3 & 3.0 & 3.0 & 100.0 \\
\cline { 2 - 5 } & Total & 100 & 100.0 & 100.0 & \\
\hline
\end{tabular}

Sumber: Data hasil pengolahan SPSS,2017

Berdasarkan table 4.1.5, menunjukan hasil responden yang telah mengisi kuisioner dimana responden mengunjungi McDonald's Lodaya sendirian dengan jumlah 13 (13\%), bersama teman dengan nilai 76 (76\%), keluarga dengan jumlah 8 (8\%) dan lainnya dengan jumlah 3 (3\%). Dengan demikian hasil tersebut menunjukan bahwa responden lebih senang mengunjungi McDonald's Lodaya bersama teman dibandingkan dengan keluarga,lainnya dan sendirian.

Tabel 4.1.6

Responden Berdasarkan Alasan Mengunjungi McDonald's

\begin{tabular}{llcccc}
\hline & & Frequency & Percent & $\begin{array}{c}\text { Valid } \\
\text { Percent }\end{array}$ & $\begin{array}{c}\text { Cumulative } \\
\text { Percent }\end{array}$ \\
\hline \multirow{3}{*}{ Valid } & keragaman menunya & 28 & 28.0 & 28.0 & 28.0 \\
\cline { 2 - 6 } & dekat dengan tempat tinggal & 25 & 25.0 & 25.0 & 53.0 \\
\cline { 2 - 6 } & kelengkapan fasilitas & 20 & 20.0 & 20.0 & 73.0 \\
\cline { 2 - 6 } & Lainnya & 27 & 27.0 & 27.0 & 100.0 \\
\cline { 2 - 6 } & Total & 100.0 & 100.0 & \\
\hline
\end{tabular}

Sumber: Data hasil pengolahan SPSS,2017

Berdasarkan table 4.6, menunjukan hasil responden yang telah mengisi kuisioner dimana responden memilih McDonald's Lodaya karena keragaman menunya dengan jumlah 28 (28\%), dekat dengan tempat tinggal dengan jumlah 25 (25\%), kelengkapan fasilitas dengan jumlah 20 (20\%) dan lainnya dengan jumlah 27 (27\%). Dengan demikian hasil tersebut menunjukan bahwa responden memilih McDonald's Lodaya karena keragaman menunya dibandingkan dengan dekat dengan tempat tinggal, kelengkapan fasilitas dan lainnya.

Tabel 4.1.7

Responden Berdasarkan Orang yang Mempengaruhi

\begin{tabular}{llcccc}
\hline & & Frequency & Percent & $\begin{array}{c}\text { Valid } \\
\text { Percent }\end{array}$ & $\begin{array}{c}\text { Cumulative } \\
\text { Percent }\end{array}$ \\
\hline \multirow{3}{*}{ Valid } & teman-teman saya & 60 & 60.0 & 60.0 & 60.0 \\
\cline { 2 - 6 } & keluarga saya & 5 & 5.0 & 5.0 & 65.0 \\
\cline { 2 - 6 } & tidak ada,saya sendiri & 35 & 35.0 & 35.0 & 100.0 \\
\cline { 2 - 6 } & Total & 100 & 100.0 & 100.0 & \\
\hline
\end{tabular}

Sumber: Data hasil pengolahan SPSS,2017

Berdasarkan table 4.1.7, menunjukan hasil responden yang telah mengisi kuisioner dimana orang yang mempengaruhi responden untuk memilih McDonald's Lodaya diperoleh data temanteman saya dengan jumlah 60 (60\%), dengan keluarga saya dengan jumlah 5 (5\%), dan tidak 
ada, saya sendiri dengan jumlah 35 (35\%). Dengan demikian hasil tersebut menunjukan bahwa responden lebih terpengaruh dengan teman-teman dibandingkan keluarga dan diri sendiri.

Tabel 4.1.8

Responden Berdasarkan Pendapat Mengenai Makanan McDonald's

\begin{tabular}{llcccc}
\hline & & Frequency & Percent & $\begin{array}{c}\text { Valid } \\
\text { Percent }\end{array}$ & Cumulative Percent \\
\hline \multirow{2}{*}{ Valid } & sangat buruk & 2 & 2.0 & 2.0 & 2.0 \\
\cline { 2 - 6 } & Baik & 98 & 98.0 & 98.0 & 100.0 \\
\cline { 2 - 6 } & Total & 100 & 100.0 & 100.0 & \\
\hline
\end{tabular}

Sumber: Data hasil pengolahan SPSS,2017

Berdasarkan table 4.1.8, menunjukan hasil responden yang telah mengisi kuisioner dimana pendapat responden mengenai makanan yang ada di McDonald's Lodaya bahwa sangat buruk dengan jumlah 2 (2\%), dan baik dengan jumlah 98 (98\%). Dengan demikian hasil tersebut menunjukan bahwa secara keseluruhan makanan yang ada di McDonald's Lodaya memiliki citra yang baik dimata responden.

\section{Indeks Jawaban Responden}

Berdasarkan rata- rata jawaban responden, maka dapat ditentukan interval penilaian sebagai berikut:

Tabel 4.2.1

Rentang Skala Indeks Jawaban Responden

\begin{tabular}{ccc}
\hline No & Rentas & Kategori \\
\hline 1 & $1,00-1,80$ & Sangat rendah \\
\hline 2 & $1,81-2,61$ & Rendah \\
\hline 3 & $2,62-3,42$ & Netral \\
\hline 4 & $3,42-4,23$ & Tinggi \\
\hline 5 & $4,24-5$ & Sangat tinggi \\
\hline
\end{tabular}

\section{Uji Validitas dan Uji Reliabilitas}

Tabel 4.3.1

Variabel X1 (Budaya Imperatif)

\begin{tabular}{llccc}
\hline No & Pernyataan & $\begin{array}{c}\text { r-product } \\
\text { moment } \\
\text { hitung }\end{array}$ & $\begin{array}{c}\text { moment } \\
\text { table } \\
\mathrm{n}=30 ; \alpha \\
=5 \%\end{array}$ & Signifikansi \\
\hline $\begin{array}{l}\text { Menu yang disediakan } \\
\text { McDonald's Lodaya sesuai } \\
\text { dengan lidah orang Indonesia }\end{array}$ & 0.448 & 0.361 & 0.013 & Valid \\
\hline
\end{tabular}




\begin{tabular}{|c|c|c|c|c|c|}
\hline 2 & $\begin{array}{l}\text { Makanan di restoran McDonald's } \\
\text { Lodaya menyediakan apa yang } \\
\text { dibutuhkan }\end{array}$ & 0.183 & 0.361 & 0.334 & Tidak Valid \\
\hline 3 & $\begin{array}{l}\text { McDonald's Lodaya menyediakan } \\
\text { beragam menu yang dapat } \\
\text { diterima oleh konsumen }\end{array}$ & 0.317 & 0.361 & 0.088 & Tidak Valid \\
\hline 4 & $\begin{array}{l}\text { McDonald's Lodaya menyediakan } \\
\text { makanan yang sehat dan } \\
\text { seimbang gizinya }\end{array}$ & 0.437 & 0.361 & 0.016 & Valid \\
\hline 5 & $\begin{array}{l}\text { McDonald's Lodaya tidak hanya } \\
\text { menyediakan makanan dan } \\
\text { minuman saja namun ada } \\
\text { beberapa layanan tambahan } \\
\text { (seperti wifi,café) }\end{array}$ & 0.569 & 0.361 & 0.001 & Valid \\
\hline 6 & $\begin{array}{l}\text { McDonald's Lodaya merupakan } \\
\text { tempat yang nyaman untuk } \\
\text { berkumpul bersama } \\
\text { keluarga,teman }\end{array}$ & 0.588 & 0.361 & 0.001 & Valid \\
\hline 7 & $\begin{array}{l}\text { McDonald's Lodaya selalu } \\
\text { menyediakan makanan dengan } \\
\text { fresh atau selalu baru dalam } \\
\text { penyajiannya }\end{array}$ & 0.731 & 0.361 & 0.000 & Valid \\
\hline 8 & $\begin{array}{l}\text { McDonald's Lodaya menyediakan } \\
\text { tempat bermain di restorannya } \\
\text { dan menyewakan untuk perayaan } \\
\text { ulang tahun }\end{array}$ & 0.573 & 0.361 & 0.001 & Valid \\
\hline 9 & $\begin{array}{l}\text { McDonald's Lodaya memiliki } \\
\text { karyawan yang ramah dan sopan } \\
\text { kepada para pengunjung }\end{array}$ & 0.635 & 0.361 & 0.000 & Valid \\
\hline 10 & $\begin{array}{l}\text { McDonald's Lodaya karyawan } \\
\text { yang cekatan atau sigap apabila } \\
\text { ada pengunjung yang } \\
\text { membutuhkan bantuan }\end{array}$ & 0.654 & 0.361 & 0.000 & Valid \\
\hline 11 & $\begin{array}{l}\text { McDonald's Lodaya memiliki } \\
\text { manajer yang bertanggung jawab }\end{array}$ & 0.464 & 0.361 & 0.010 & Valid \\
\hline
\end{tabular}




\begin{tabular}{|c|c|c|c|c|c|}
\hline & $\begin{array}{l}\text { atas para karyawan yang } \\
\text { dipekerjakannya }\end{array}$ & & & & \\
\hline 12 & $\begin{array}{l}\text { Karyawan McDonald's Lodaya } \\
\text { menggunakan seragam dan baju } \\
\text { yang baik saat bekerja }\end{array}$ & 0.418 & 0.361 & 0.021 & Valid \\
\hline 13 & $\begin{array}{l}\text { Harga menu yang ada di } \\
\text { McDonald's Lodaya tidak terlalu } \\
\text { mahal }\end{array}$ & 0.514 & 0.361 & 0.004 & Valid \\
\hline 14 & $\begin{array}{l}\text { Harga menu yang ada di } \\
\text { McDonald's Lodaya tidak terlalu } \\
\text { mahal }\end{array}$ & 0.328 & 0.361 & 0.077 & Valid \\
\hline 15 & $\begin{array}{l}\text { Porsi makanan di McDonald's } \\
\text { Lodaya pas sebagai kudapan }\end{array}$ & 0.501 & 0.361 & 0.005 & Valid \\
\hline 16 & $\begin{array}{l}\text { Biaya pajak yang diberikan } \\
\text { restoran McDonald's adalah } \\
\text { sepadan }\end{array}$ & 0.554 & 0.361 & 0.002 & Valid \\
\hline
\end{tabular}

Sumber: Data hasil pengolahan SPSS,2017

Berdasarkan table 4.3.1 diperoleh nilai r-product moment hitung dari pernyataan (indicator) 1, 4, $5,6,7,8,9,10,11,12,13,14,15,16$ dari variabel X1 (Budaya Imperatif) yaitu 0.013; 0.437; $0.569 ; 0.588 ; 0.731 ; 0.573 ; 0.635 ; 0.654 ; 0.464 ; 0.418 ; 0.514 ; 0.328 ; 0.501 ; 0.554$ lebih besar dari r-product moment table $(\mathrm{n}=30 ; \alpha=5 \%)=0,361$ yang didukung oleh nilai signifikansi dibawah 5\%; dengan demikian pernyataan indicator 1, 4, 5, 6, 7, 8, 9,10,11,12,13,14,15, 16 variabel X1 dinyatakan valid. Dapat disimpulkan pernyataan 1,4, 5, 6, 7, 8, 9, 10, 11, 12, 13, 14, 15, 16 dinyatakan valid dan dapat digunakan sebagai penelitian kuisioner selanjutnya. Sedangkan peryataan indicator 2 dan 3 dari variabel $X 1$ yaitu $0.183 ; 0.317$ lebih kecil dari $r$ product $(n=30 ; \alpha=5 \%)=0,361$ yang didukung oleh nilai signifikansi diatas $5 \%$. Dengan demikian peryantaan indicator 2 dan 3 variabel X1 dinyatakan tidak valid. Dapat disimpulkan pernyataan 2 dan 3 dinyatakan tidak valid dan tidak dapat digunakan sebagai penelitian kuisioner selanjutnya.

Tabel 4.3.2

Variabel X2 (Budaya Adiafora)

\begin{tabular}{|c|c|c|c|c|c|}
\hline \multirow[b]{2}{*}{ No } & \multirow[b]{2}{*}{ Pernyataan } & \multicolumn{3}{|c|}{ r-product } & \multirow[b]{2}{*}{ Kesimpulan } \\
\hline & & $\begin{array}{l}r \text { - product } \\
\text { moment } \\
\text { hitung }\end{array}$ & $\begin{array}{l}\text { moment } \\
\quad \text { table } \\
\mathrm{n}=30 ; \alpha \\
\quad=5 \%\end{array}$ & Signifikansi & \\
\hline 1 & $\begin{array}{l}\text { McDonald's Lodaya memiliki delivery } \\
\text { yang cepat dalam pengantaran } \\
\text { makanan }\end{array}$ & 0.315 & 0.361 & 0.090 & Tidak Valid \\
\hline 2 & $\begin{array}{l}\text { McDonald's Lodaya memiliki delivery } \\
\text { yang baik dalam pelayanan }\end{array}$ & 0.547 & 0.361 & 0.002 & Valid \\
\hline
\end{tabular}




\begin{tabular}{|c|c|c|c|c|c|}
\hline 3 & $\begin{array}{l}\text { McDonald's Lodaya memiliki sistem } \\
\text { delivery yang canggih dalam } \\
\text { melayani konsumen }\end{array}$ & 0.652 & 0.361 & 0.000 & Valid \\
\hline 4 & $\begin{array}{l}\text { McDonald's Lodaya selalu menerima } \\
\text { bahan makanan yang masih fresh }\end{array}$ & 0.571 & 0.361 & 0.001 & Valid \\
\hline 5 & $\begin{array}{l}\text { Setiap ada event tertentu, } \\
\text { McDonald's Lodaya memberikan } \\
\text { potongan untuk setiap menu }\end{array}$ & 0.629 & 0.361 & 0.000 & Valid \\
\hline 6 & $\begin{array}{l}\text { McDonald's Lodaya selalu } \\
\text { memberikan promosi satu gratis satu } \\
\text { atau gratis menu yang lain dengan } \\
\text { kupon atau brosur yang disebar }\end{array}$ & 0.652 & 0.361 & 0.000 & Valid \\
\hline 7 & $\begin{array}{l}\text { Terkadang McDonald's Lodaya } \\
\text { memberikan free tax untuk } \\
\text { pembelian yang menggunakan } \\
\text { maksimal pembeliannya }\end{array}$ & 0.581 & 0.361 & 0.001 & Valid \\
\hline
\end{tabular}

McDonald's Lodaya melakukan promosi secara gentar dan terus-

8 menerus di setiap ada acara tertentu (misalkan:ulang tahun atau promo

$\begin{array}{llll}0.427 & 0.361 & 0.019 & \text { Valid }\end{array}$
film animasi seperti Despicable Me 3)

\begin{tabular}{lllll}
\hline $9 \begin{array}{l}\text { McDonald's Lodaya memberikan } \\
\text { pelayanan yang terbaik kepada } \\
\text { konsumen }\end{array}$ & 0.630 & 0.361 & 0.000 & Valid \\
\hline $\begin{array}{l}\text { McDonald's Lodaya selalu mencari } \\
\text { cara agar dapat selalu dekat dengan } \\
\text { konsumennya }\end{array}$ & 0.639 & 0.361 & 0.000 & Valid \\
\hline $\begin{array}{l}\text { McDonald's Lodaya selalu } \\
\text { menjadikan kebutuhan konsumen } \\
\text { nomor satu }\end{array}$ & 0.642 & 0.361 & 0.000 & Valid \\
\hline $\begin{array}{l}\text { McDonald's Lodaya memberikan } \\
\text { kenyamanan diluar maupun di dalam } \\
\text { restorannya untuk konsumen }\end{array}$ & 0.483 & 0.361 & 0.007 & Valid
\end{tabular}


Berdasarkan table 4.3.2 diperoleh nilai r-product moment hitung dari pernyataan (indicator) 2, 3, 4, 5, 6, 7, 8, 9, 10, 11, 12 dari variabel X2 (Budaya Adiafora) yaitu 0.547; 0.652; 0.571; 0.629; $0.652 ; 0.581 ; 0.427 ; 0.630 ; 0.639 ; 0.642 ; 0.483$ lebih besar dari r-product moment table $(\mathrm{n}=30$; $\alpha=5 \%)=0,361$ yang didukung oleh nilai signifikansi dibawah $5 \%$; dengan demikian pernyataan indicator 2, 3, 4, 5, 6, 7, 8, 9, 10, 11, 12 variabel X2 dinyatakan valid. Dapat disimpulkan pernyataan 2, 3, 4, 5, 6, 7, 8, 9, 10, 11, 12 dinyatakan valid dan dapat digunakan sebagai penelitian kuisioner selanjutnya. Sedangkan peryataan indicator 1 dari variabel X2 yaitu 0.315 lebih kecil dari r-product $(n=30 ; \alpha=5 \%)=0,361$ yang didukung oleh nilai signifikansi diatas $5 \%$. Dengan demikian peryantaan indicator 1 variabel X2 dinyatakan tidak valid. Dapat disimpulkan pernyataan 1 dinyatakan tidak valid dan tidak dapat digunakan sebagai penelitian kuisioner selanjutnya.

Tabel 4.3.3

Variabel X3 (Budaya Eksklusif)

\begin{tabular}{|c|c|c|c|c|c|}
\hline No & Pernyataan & $\begin{array}{l}r \text { - product } \\
\text { moment } \\
\text { hitung }\end{array}$ & $\begin{array}{c}r \text { - product } \\
\text { moment } \\
\text { table } \\
\mathrm{n}=30 ; \alpha \\
=5 \%\end{array}$ & Signifikansi & Kesimpulan \\
\hline 1 & $\begin{array}{l}\text { Menu di McDonald's Lodaya } \\
\text { bersifat halal (tidak mengandung } \\
\text { lemak babi ) }\end{array}$ & 0.653 & 0.361 & 0.000 & Valid \\
\hline 2 & $\begin{array}{l}\text { Makanan di McDonald's Lodaya } \\
\text { sudah lulus uji tes BPOM } \\
\text { sebelumnya }\end{array}$ & 0.772 & 0.361 & 0.000 & Valid \\
\hline 3 & $\begin{array}{l}\text { Makanan di McDonald's Lodaya } \\
\text { terasa nikmat apabila disantap di } \\
\text { tempat ataupun di bawa pulang }\end{array}$ & 0.477 & 0.361 & 0.008 & Valid \\
\hline 4 & $\begin{array}{l}\text { Makanan di McDonald's Lodaya } \\
\text { mengandung bahan-bahan yang } \\
\text { layak untuk di konsumsi }\end{array}$ & 0.678 & 0.361 & 0.000 & Valid \\
\hline 5 & $\begin{array}{l}\text { Pada acara tertentu, McDonald's } \\
\text { Lodaya menghargai konsumen } \\
\text { yang sedang merayakan acara } \\
\text { tersebut (misalkan: bulan puasa) }\end{array}$ & 0.651 & 0.361 & 0.000 & Valid \\
\hline 6 & $\begin{array}{l}\text { McDonald's Lodaya selalu } \\
\text { menerapkan sistem restoran yang } \\
\text { baik agar konsumen tidak kecewa }\end{array}$ & 0.737 & 0.361 & 0.000 & Valid \\
\hline 7 & $\begin{array}{l}\text { McDonald's Lodaya merupakan } \\
\text { restoran yang sesuai dengan } \\
\text { hukum yang berlaku di Indonesia }\end{array}$ & 0.670 & 0.361 & 0.000 & Valid \\
\hline
\end{tabular}




\begin{tabular}{|c|c|c|c|c|c|}
\hline 8 & $\begin{array}{l}\text { McDonald's Lodaya merupakan } \\
\text { restoran yang mengutamakan } \\
\text { kesopanan }\end{array}$ & 0.793 & 0.361 & 0.000 & Valid \\
\hline
\end{tabular}

Sumber: Data hasil pengolahan SPSS,2017

Berdasarkan table 4.3.3 diperoleh nilai r-product moment hitung secara berturut-turut untuk (8) delapan pernyataan (indicator) dari variable X3 (Budaya Eksklusif) yaitu $0.653 ; 0.772 ; 0.477$; $0.678 ; 0651 ; 0.737 ; 0.670 ; 0.793$ lebih besar dari $r$ product moment table $(n=30 ; \alpha=5 \%)=$ 0,361 yang didukung oleh nilai signifikansi dibawah 5\% ; dengan demikian maka seluruh pernyataan indicator variable X3 dinyatakan valid. Dapat disimpulkan pernyataan 1 sampai dengan 8 dinyatakan valid dan dapat digunakan sebagai penelitian kuisioner selanjutnya.

Tabel 4.3 .4

Variabel Y ( Keputusan Pembelian)

\begin{tabular}{|c|c|c|c|c|c|}
\hline No & Pernyataan & $\begin{array}{l}r \text { - product } \\
\text { moment } \\
\text { hitung }\end{array}$ & $\begin{array}{c}r \text { - product } \\
\text { moment } \\
\text { table } \\
\mathrm{n}=30 ; \alpha \\
=5 \%\end{array}$ & Signifikansi & Kesimpulan \\
\hline 1 & $\begin{array}{l}\text { Saya membeli makanan di } \\
\text { McDonald's Lodaya karena dekat } \\
\text { dengan kantor/rumah saya }\end{array}$ & 0.424 & 0.361 & 0.019 & Valid \\
\hline 2 & $\begin{array}{l}\text { Saya membeli makanan di } \\
\text { McDonald's Lodaya karena sudah } \\
\text { bersetifikat }\end{array}$ & 0.670 & 0.361 & 0.000 & Valid \\
\hline 3 & $\begin{array}{l}\text { Saya membeli makanan di } \\
\text { McDonald's Lodaya karena menu } \\
\text { yang saya mau ada disana }\end{array}$ & 0.453 & 0.361 & 0.000 & Valid \\
\hline 4 & $\begin{array}{l}\text { Saya membeli makanan di } \\
\text { McDonald's Lodaya karena tidak } \\
\text { ada pilihan lain }\end{array}$ & 0.423 & 0.361 & 0.20 & Valid \\
\hline 5 & $\begin{array}{l}\text { Saya mengetahui McDonald's } \\
\text { Lodaya dari kerabat saya }\end{array}$ & 0.324 & 0.361 & 0.081 & Tidak Valid \\
\hline 6 & $\begin{array}{l}\text { Saya melihat iklan yang ada di } \\
\text { televisi atau di jalan raya sehingga } \\
\text { mengetahui McDonald's Lodaya }\end{array}$ & 0.555 & 0.361 & 0.001 & Valid \\
\hline 7 & $\begin{array}{l}\text { Saya mencari tahu sendiri tentang } \\
\text { McDonald's Lodaya }\end{array}$ & 0.453 & 0.361 & 0.012 & Valid \\
\hline
\end{tabular}




\begin{tabular}{llllll}
\hline 8 & $\begin{array}{l}\text { Saya mengetahui McDonald's } \\
\text { Lodaya karena sering melewatinya }\end{array}$ & 0.304 & 0.361 & 0.102 & Tidak Valid \\
\hline
\end{tabular}

\begin{tabular}{|c|c|c|c|}
\hline $\begin{array}{l}\text { Saya akan memberikan } \\
\text { rekomendasi restoran McDonald's } \\
\text { Lodaya kepada teman saya }\end{array}$ & 0.719 & 0.361 & 0.000 \\
\hline
\end{tabular}

\begin{tabular}{|c|c|c|c|c|c|}
\hline 10 & $\begin{array}{l}\text { Saya akan memberikan } \\
\text { rekomendasi restoran McDonald's } \\
\text { Lodaya kepada Keluarga saya }\end{array}$ & 0.772 & 0.361 & 0.000 & Valid \\
\hline 11 & $\begin{array}{l}\text { Saya aakn memberikan } \\
\text { rekomendasi restoran Mcdonald's } \\
\text { Lodaya kepada kerabat dekat saya }\end{array}$ & 0.692 & 0.361 & 0.000 & Valid \\
\hline
\end{tabular}

\begin{tabular}{|c|c|c|c|c|c|}
\hline 12 & $\begin{array}{l}\text { Saya akan memberikan } \\
\text { rekomendasi restoran McDonald's } \\
\text { Lodaya kepada orang yang baru } \\
\text { saya temui }\end{array}$ & 0.639 & 0.361 & 0.000 & Valid \\
\hline 13 & $\begin{array}{l}\text { Dimasa mendatang saya pasti akan } \\
\text { mengunjungi McDonald's Lodaya } \\
\text { kembali }\end{array}$ & 0.507 & 0.361 & 0.004 & Valid \\
\hline 14 & $\begin{array}{l}\text { Jika saya memerlukan makanan } \\
\text { sebagaimana yang disajikan } \\
\text { McDonald's Lodaya saya akan } \\
\text { kembali }\end{array}$ & 0.479 & 0.361 & 0.007 & Valid \\
\hline 15 & $\begin{array}{l}\text { Apabila saya membutuhkan tempat } \\
\text { untuk menyelenggarakan acara } \\
\text { saya akan kembali ke McDonald's } \\
\text { Lodaya }\end{array}$ & 0.679 & 0.361 & 0.000 & Valid \\
\hline 16 & $\begin{array}{l}\text { Jika saya memerlukan pelayanan } \\
\text { yang baik dalam penyajian saya } \\
\text { akan kembali ke McDonald's } \\
\text { Lodaya }\end{array}$ & 0.558 & 0.361 & 0.001 & Valid \\
\hline
\end{tabular}

Sumber: Data hasil pengolahan SPSS,2017

\section{Pengaruh Budaya Imperatif (X1) terhadap Keputusan Pembelian (Y)}

Penelitian ini menunjukan hubungan antara budaya imperatif terhadap keputusan pembelian dapat diterima, hal ini ditunjukan dengan nilai t-hitung sebesar 4.202 yang dimana lebih besar dibandingkan t-tabel 1.66 dan didukung oleh nilai signifikansi 0.000 lebih kecil dibandingkan dengan 0.05 yang dimana variabel tersebut berpengaruh signifikan terhadap keputusan pembelian. 


\section{Pengaruh Budaya Adiafora (X2) terhadap Keputusan Pembelian (Y)}

Penelitian ini menunjukan hubungan antara budaya adiafora terhadap keputusan pembelian dapat diterima, hal ini ditunjukan dengan nilai t-hitung sebesar 2.196 yang dimana lebih besar dibandingkan t-tabel 1.66 dan didukung oleh nilai signifikansi 0.031 lebih kecil dibandingkan dengan 0.05 yang dimana variabel tersebut berpengaruh signifikan terhadap keputusan pembelian.

\section{Pengaruh Budaya Eksklusif (X3) terhadap Keputusan Pembelian (Y)}

Penelitian ini menunjukan hubungan antara budaya eksklusif terhadap keputusan pembelian tidak dapat diterima, hal ini ditunjukan dengan nilai t-hitung sebesar 0.745 yang dimana lebih kecil dibandingkan t-tabel 1.66 dan didukung oleh nilai signifikansi 0.458 lebih besar dibandingkan dengan 0.05 yang dimana variabel tersebut tidak signifikan terhadap keputusan pembelian.

\section{Pembahasan}

Berdasarkan hasil kuesioner dan pengolahan data kuesioner menggunakan program SPSS yang telah dilakukan, maka pembahasan terhadap hipotesis penelitian adalah yang menyatakan Budaya Imperatif berpengaruh secara positif dan signifikan terhadap keputusam pembelian, penelitian ini membuktikan teori yang disampaikan oleh Czinkota dan Ronkainen (2004) menyatakan budaya imperative yaitu merupakan suatu budaya asing dalam pemasaran internasional yang dimana harus diterapkan oleh seluruh perusahaan yang melakukan perdagangan internasional agar dapat menyesuaikan diri dengan negara yang menjadi tujuannya untuk melakukan perdagangan internasional tersebut. Apabila, budaya imperative diterapkan dengan baik pastinya perusahaan akan berkembang lebih baik di negara-negara yang memang menjadi tujuannya untuk mendirikan perusahaan berbasis international maupun franchaise seperti McDonald's.

McDonald's harus menerapkan dan mempelajari budaya imperatif dalam perusahaannya agar dapat berkembang dan lebih maju lagi untuk memenuhi kebutuhan para konsumennya di setiap negara termasuk Indonesia. Maka, Manager yang ada di McDonadl's Lodaya harus mengetahui dan menerapkan budaya imperative dalam perusahaannya agar menarik hati konsumen dan mendapatkan keputusan pembelian dari konsumen. Maka, Manager perlu memperhatikan budaya imperatif yang sudah terbukti secara signifikan terhadap keputusan pembelian. Apabila saya sebagai manager dari McDonald's saya akan meningkatkan kinerja para karyawan dan lebih memperhatikan segala sesuatunya mulai dari menu maupun bangunan yang berdiri kokoh. Yang menyatakan budaya adiafora berpengaruh secara positif dan signifikan terhadap keputusam pembelian, penelitian ini membuktikan teori yang disampaikan oleh Kotler (2009) menyatakan budaya adiafora yaitu merupakan suatu budaya asing dalam pemasaran internasional yang dimana harus diterapkan oleh seluruh perusahaan yang melakukan perdagangan internasional agar dapat menyesuaikan diri dengan negara yang menjadi tujuannya untuk melakukan perdagangan internsional tersebut.

Apabila, budaya adiafora diterapkan dengan baik pastinya perusahaan akan berkembang lebih baik di negara-negara yang memang menjadi tujuannya untuk mendirikan perusahaan berbasis international maupun franchaise seperti McDonald's. McDonald's harus menerapkan dan mempelajari budaya adiafora dalam perusahaannya agar dapat berkembang dan lebih maju lagi untuk memenuhi kebutuhan para konsumennya di setiap negara termasuk Indonesia yang merupakan negara hokum dan harus menerapkan serta menyesuaikan dengan hukum tersebut karena budaya adiafora adalah budaya dalam pemasaran internasional dan merupakan sesuatu yang boleh dilakukan dan yang tidak dan perusahaan harus melihat itu. Maka, Manager yang ada di McDonadl's Lodaya harus mengetahui dan menerapkan budaya adiafora dengan segala syarat agar tidak salah dalam mengambil langkah dalam perusahaannya untuk menarik hati konsumen dan mendapatkan keputusan pembelian dari konsumen. Maka, Manager perlu memperhatikan 
budaya imperatif yang sudah terbukti secara signifikan terhadap keputusan pembelian. Apabila saya sebagai manager dari McDonald's saya akan memikirkan tentang menu-menu akanan yang ada di sana untuk di inovasikan lagi yang pastinya sesuai dengan lidah masyarakat Indonesia agar meningkatkan citra dari McDonald's.

Dinyatakan budaya eksklusif berpengaruh secara positif dan tidak signifikan terhadap keputusan pembelian, penelitian ini membuktikan teori yang disampaikan oleh Parsudi (2003) menyatakan budaya eksklusif yaitu merupakan suatu budaya asing dalam pemasaran internasional yang dimana harus diterapkan oleh seluruh perusahaan yang melakukan perdagangan internasional agar dapat menyesuaikan diri dengan negara yang menjadi tujuannya untuk melakukan perdagangan internsional tersebut. Apabila, budaya eksklusif diterapkan dengan baik pastinya perusahaan akan berkembang lebih baik di negara-negara yang memang menjadi tujuannya untuk mendirikan perusahaan berbasis international maupun franchaise seperti McDonald's.

McDonald's harus menerapkan dan mempelajari budaya eksklusif dalam perusahaannya agar dapat berkembang dan lebih maju lagi untuk memenuhi kebutuhan para konsumennya di setiap negara termasuk Indonesia. Maka, Manager yang ada di McDonadl's Lodaya harus mengetahui dan menerapkan budaya eksklusif dalam perusahaannya agar menarik hati konsumen dan mendapatkan keputusan pembelian dari konsumen. Maka, Manager perlu memperhatikan budaya eksklusif yang sudah terbukti secara tidak signifikan terhadap keputusan pembelian. Apabila saya menjadi seorang manager dari McDonald's saya akan terus meningkatkan budata eksklusif dalam perusahaan saya agar sesuai dengan undang-undang yang ada di negara Indonesia dan membuat para konsumen menentukan pilihannya kepada McDonald's.

\section{Kesimpulan}

Berdasarkan hasil analisis data yang telah dilakukan terhadap seluruh data yang diperoleh, maka dapat diambil kesimpulan sebagai berikut:

1. Budaya Imperatif secara parsial berpengaruh positif terhadap keputusan pembelian. Hal ini dibuktikan dengan nilai t hitung lebih besar daripada nilai t tabel yaitu $4.202>1.66$ dengan tingkat signifikansi $0.000<0.05$.

2. Budaya Adiafora secara parsial berpengaruh positif terhadap keputusan pembelian. Hal ini dibuktikan dengan nilai t hitung lebih besar daripada nilai t tabel $2.196>1.66$ dengan tingkat signifikansi $0.031>0.05$.

3. Budaya Eksklusif secara parsial berpengaruh tidak positif terhadap keputusan pembelian. Hal ini dibuktikan dengan nilai t hitung lebih kecil daripada nilai t tabel yaitu $0.745<1.66$ dengan tingkat signifikansi $0.458>0.05$.

4. Secara simultan variabel Budaya Imperatif, Budaya Adiafora dan Budaya Eksklusif memiliki pengaruh yang signifikan terhadap Keputusan Pembelian. Hal ini dibuktikan dengan nilai $F$ hitung lebih besar daripada nilai $F$ tabel yaitu $21.815>2.70$ dengan tingkat signifikansi 0.000 $<0.05$.

\section{Saran}

Berdasarkan kesimpulan yang telah dikemukakan, maka diberikan beberapa saran yang diharapkan dapat meningkatkan kepuasan pelanggan McDonald's Lodaya. Adapun saran-saran yang diberikan bagi perusahaan adalah sebagai berikut:

1. McDonald's Lodaya Bogor harus lebih memperhatikan etika dalam penyajian makanan bahwa tidak diperbolehkan menggunakan bahan-bahan makanan yang sudah kadaluarsa ataupun berpengawet karena akan menjadi dampak buruk bagi konsumen yang sudah 
percaya terhadap restoran McDonald's maka dari itu diharuskan, mengandung bahanbahan yang layak untuk dikonsumsi oleh para konsumen.

2. McDonald's harus menyediakan makanan yang seimbang gizinya,bukan hanya memberikan cita rasa yang baik disetiap makanannya tetapi juga memberikan gizi yang seimbang disetiap menunya agar lebih menarik perhatian konsumen. Karena saya melihat pada poin 4 dalam indeks jawaban responden pada variabel X1 pernyataan tersebut bernilai rendah.

3. McDonald's Lodaya dapat memberikan harga yang sesuai dengan yang didapatkan konsumen atau memberikan potongan harga atau diskon untuk disetiap pembeliannya berupa kupon atau undian berhadiah. Karena saya melihat pada poin 13 dalam indeks jawaban responden pada variabel $\mathrm{X} 1$ pernyataan tersebut bernilai rendah.

4. McDonald's Lodaya dapat meningkatkan kinerja para karyawannya untuk memenuhi kebutuhan pelanggan termasuk dalam kegiatan pengantaran makanan atau delivery yang bertanggung jawab dan cepat dalam melayani para konsumen. Karena saya melihat pada poin 1 dalam indeks jawaban responden pada variabel $\mathrm{X} 2$ pernyataan tersebut bernilai rendah.

5. McDonald's Lodaya harus lebih sering berpromosi agar menambah keloyalitasan konsumen terhadap McDonald's seperti, memberi brosur beli dua gratis satu untuk pembelian ice cream ataupun burgernya dan pada menu lainnya. Karena saya melihat pada poin 5,6 dan 7 dalam indeks jawaban responden pada variabel X2 pernyataan tersebut bernilai rendah.

\section{DAFTAR PUSTAKA}

Czinkota, M. \& 1. Ronkainen 2004. "Global Marketing 2000: A Marketing Survival Guide," Marketing Management.

Ferdinand, Augusty. 2006. Metode Penelitian Manajemen: Pedoman Penelitian untuk skripsi, Tesis dan Disertai Ilmu Manajemen. Semarang: Universitas Diponegoro.

Ghozali, Imam. 2005. Aplikasi Analisis Multivariate dengan program SPSS, Badan Penerbit Universitas Diponegoro, Semarang.

Ghozali, Imam. 2009. “Aplikasi Analisis Multivariate dengan Program SPSS “. Semarang : UNDIP.

Graham, Jhon L dan Cateora, Philip R.. 2007. Pemasaran Internasional Edisi 13. Jakart: Salemba Empat.

Keegan, J. wareen dan Green, C.Mark (2002). Global Marketing. Ninth Edition.

Kotabe, Masaaki dan Helsen, Kristiaan (2004).Global Marketing Management. John Wiley \& Sons; 5th Edition International Student Version.

Kotler, Philip dan Amstrong,Gary. (2008). Prinsip-prinsip Pemasaran Edisi Bahasa Indonesia. Erlangga, Jakarta.

Kottler dan Keller, (2009). Manajemen Pemasaran. Jilid I. edisi ke 13 Jakarta : Erlangga.

Kotler, Philip. (2005). Manajemen Public Relation. Jakarta : Gramedia Pustaka Utama

Kotler, Philip (2007). Marketing Management : Analiysis, Planning, Implementation and Control Ninth Edition, Prentice Hall, Inc, Upper Saddle River, New Jersey. 
Kotler, Philip. (2009). Manajemen Pemasaran, edisi millennium 2, PT Indeks : Jakarta.

Nugroho, Setiadi. (2008.) Perilaku Konsumen Konsep dan Implikasi untuk Strategi dan Penelitian Pemasaran. Jakarta : Kencana Prenada Group.

Setiawan, B. (2013). Menganalisa statistik bisnis dan ekonomi dengan SPSS 21. Yogyakarta: Andi.

Setiawan, B. (2014). Customer Satisfaction Index Model on Three Level Of Socioeconomic Status In Bogor Case Study: Customer Satisfaction on Branded Cooking Oil Product. ASEAN Marketing Journal.

Setiawan, B. (2015). Teknik Praktis Analisis Data Penelitian Sosial \& Bisnis dengan SPSS. Yogakarta: CV Andi Offset.

Setiawan, B., Puspitasari, R., \& Manurung, T. M. S. (2016). The Existence of Islamic Banking in Indonesia from Non-Muslims Perceptions. ASEAN Marketing Journal, 81-96.

Setiawan, B. (2017). Strategi Pengembangan Usaha Kerajinan Bambu di Wilayah Kampung Pajeleran Sukahati Kecamatan Cibinong Kabupaten Bogor.

Setiawan, B., \& Panduwangi, M. (2017, August). Measurement Of Islamic Banking Attributes In Indonesia. In Proceedings of the Global Conference on Business and Economics Research (GCBER) (pp. 14-15).

Setiawan, B. (2017). Teknik Hitung Manual Analisis Regresi Linear Berganda Dua Variabel Bebas.

Setiawan, B. (2018). A Critical Review of the Business Agility Literature in the Advancement of Information and Communication Technology.

Sugiyono (2007). Metode Penelitian Pendidikan Pendekatan Kuantitatif ,Kualitatif dan R\&D . Bandung : ALFABETA.

Terpstra, V. and R. Sarathy, International Marketing, Chicago: Dryden Press, 1994.

Tjiptono, Fandy (2011) Manajemen Jasa. Penerbit Andi, Yogyakarta.

https://www.mcdonalds.co.id/tentang-mcdonalds/info-perusahaan/sejarah-mcdonalds. 